\title{
Quantitative Analysis of Selenium in Staple Foodstuffs from Kanam Local Government Area, North-Central Nigeria
}

\author{
Kiri H Jaryum ${ }^{* 1,2}$, Z S C Okoye ${ }^{2}$ and Barbara J Stoecker ${ }^{1}$ \\ ${ }^{1}$ Department of Nutritional Sciences, College of Human Science, Oklahoma State University, Stillwater OK 74078, USA \\ ${ }^{2}$ Department of Biochemistry, Faculty of Medical Sciences, University of Jos, P.M.B. 2084, Jos, Nigeria
}

\begin{abstract}
Received: 15 April, 2019; Accepted: 02 May, 2019; Published: 17 May, 2019
*Corresponding author: Kiri H Jaryum, Department of Nutritional Sciences, College of Human Science, Oklahoma State University, Stillwater OK 74078, USA, Tel: +234 803045 6424, E-mail: jaryumkh@unijos.edu.ng
\end{abstract}

\begin{abstract}
Background: Although selenium was, for decades, considered toxic, many animal diseases has been found to respond to selenium. Selenium is, therefore, an essential trace element. Selenium is essential for human nutrition where it is a constituent of more than two dozen selenoproteins that play critical roles in reproduction, thyroid hormone metabolism, DNA synthesis, and protection from oxidative damage and infection. Selenium concentrations in plantbased foods vary widely by geographic location. This research was aimed at determining the amount of selenium in the local foodstuffs from Kanam Local Government Area in north-central Nigeria.
\end{abstract}

Methods: Staple foodstuffs were selected across all the sections of the research area. Samples were homogenized in a ceramic mortar to obtain homogeneous samples with particle size $>300 \mu \mathrm{m}$. These were digested using a diluted oxidant mixture containing $1 \mathrm{ml}$ deionised $\mathrm{H} 2 \mathrm{O}+0.5 \mathrm{ml}$ double-distilled HNO3. Selenium content was determined using the inductively coupled-mass spectrophotometry technique. Data obtained were analysed using the student's t-test and results were presented as means and standard deviations. A probability level of $p<0.05$ was considered statistically significant.

Results: All the foodstuffs contained quantities of selenium high enough to meet the recommended daily allowance for all categories. Grain varied widely in their selenium content with white sorghum containing the lowest $(6.16 \pm 3.97 \mu \mathrm{g} / \mathrm{g})$ and red sorghum containing the highest $(14.19 \pm 7.22 \mu \mathrm{g} / \mathrm{g})$ followed by cowpea $(13.05 \pm 8.79 \mu \mathrm{g} / \mathrm{g})$.

Conclusion: These values suggest that a diet well balanced in other nutrients is probably also nutritionally adequate with regard to selenium, although possible effects of cooking, processing, geographical variation and biological availability remain to be investigated.

Key Words: Staple Grains; Kanam; Selenium; North-Central Nigeria

\section{Introduction}

According to Oldfield, selenium (Se) was discovered in 1817 by Jacob Berzelius when investigating the chemicals responsible for outbreaks of ill health among workers in a Swedish sulphuric acid plant [1]. It was, later on, shown that selenium prevents liver necrosis in rats [2]. Despite earlier concerns for selenium toxicity, certain animal diseases have been found to respond to selenium [3, 4]. Selenium is, therefore, an essential trace element occurring in organic (selenomethionine and selenocysteine) and inorganic (selenate and selenite) forms. The organic form is found predominantly in grains, fish, meat, poultry, eggs and dairy products, and enters the food chain via plant consumption. Selenium is essential for human nutrition where it is a constituent of more than two dozen selenoproteins (such as glutathione peroxidase and selenoprotein P) that play critical roles in reproduction, thyroid hormone metabolism, DNA synthesis and protection from oxidative damage and infection [5]. For instance, selenium improved glutathione peroxidase and CD4 count in HIV positive Nigerian patients [6-8]. Selenium is also found to exert a positive influence on male reproductive function and accelerated gastric ulcer healing in an animal study [9]. The mineral has also been shown to possess insulinotropic antioxidant, and anticancer effects [10-12]. Selenium, among other functions, reduced susceptibility to infection in rats [13].

Selenium deficiency has been associated with a number of diseases including Keshan disease, a myocardial disease with necrotic lesions, among others. Clinically, Keshan disease showed acute or chronic episode of a heart disease characterized by cardiogenic shock, enlarged heart, congestive heart failure, and irregular heartbeat (arrhythmia) [15].

In terms of distribution, there is marked geographic variability of Se in food related to local soil content [16]. The amount of selenium in a given type of plant-based food depends on the amount of selenium in the soil (and other factors, such as soil pH, amount of organic matter in the soil), and whether the selenium is in a form that is capable of being taken up by plant $[11,17]$. Although the selenium content of a wide variety of foodstuffs has been surveyed in the West African Food Composition Table and in other literatures, there exist few data concerning amounts of selenium in foods consumed by Nigeria [18]. Therefore, this research was aimed at determining the amount of selenium in the local foodstuffs from Kanam Local Government Area in northcentral Nigeria with a view to establishing the daily dietary intake of selenium of the populace and comparing with recommended dietary allowance. 


\section{Materials and Methods}

\section{Samples}

Foods samples representing a cross section of the northcentral Nigerian diet were chosen for analysis. Samples were obtained from farmlands in Kanam Local Government Area of Plateau State, Nigeria. Staple foodstuffs were selected in all cases. All samples were assayed as obtained from farmlands with no cooking or drying performed, since selenium might be lost as a result of these processes.

\section{Preparation of samples}

Samples were homogenized in a ceramic mortar to obtain homogeneous samples. Only edible portions were used with the husks being discarded in most cases (particle size $>300 \mu \mathrm{m}$ ). Sample masses ranging from 0.192 to $0.223 \mathrm{~g}$ (average $0.208 \mathrm{~g}$ ) were weighed on Denver Instrument M - 310 (Aldinger Company, USA) weighing balance. All sample handling was performed wearing disposable, powder-free, latex gloves in clean areas. A combination of wet and dry ashing technique, adapted (with modification) from Hill et, al was used in the preparation of the food samples [19].

These were digested using a diluted oxidant mixture $(1 \mathrm{ml}$ deionised $\mathrm{H}_{2} \mathrm{O}+0.5 \mathrm{ml}$ double-distilled $\mathrm{HNO}_{3}$ ). The samples, in 13 $\mathrm{x} 100 \mathrm{~mm}$ borosilicate tubes were then placed in a heating block (Isotemp Dry Bath 145, Fisher Scientific Inc., Bohemia, NY, USA) and hydrogen peroxide $(0.5 \mathrm{ml})$ was added to each to complete the first step of the digestion process. The operating temperature for this step was $95 \mathrm{oC}$. At the end of this initial digestion, almost all the samples gave a black mass residue. The tubes are then placed upright in inverted $1000 \mathrm{ml}$ glass beaker, covered with a watch glass, and placed in a muffled furnace (Ashing Oven Lindberg, USA).

Furnace temperature was set to increase at $50 \mathrm{oC} / \mathrm{h}$ from an initial $100 \mathrm{oC}$, to $375 \mathrm{oC}$. The temperature was held at $375 \mathrm{oC}$ for $48 \mathrm{~h}$. Thereafter, it decreased at the same rate as it was increased until it reached room temperature. After cooling, samples were removed from the furnace and $0.20 \mathrm{ml}$ (i.e. $200 \mu \mathrm{l}$ ) of deionised water [obtained from a Milli - Q water purification system (Millipore, Belford, MA, USA)] and $0.20 \mathrm{ml}(200 \mu \mathrm{l})$ of doubledistilled nitric acid (GFS Chemicals, Inc., Colunbus, OH, USA) were added to each.

Tubes were, again, placed in heating blocks (Isotemp Dry Bath 145, Fisher Scientific Inc., Bohemia, NY, USA) and the temperature was raised to $90 \mathrm{oC}$ first and then, $95 \mathrm{oC}$. Hydrogen peroxide $(50 \%)$ was added in $0.10 \mathrm{ml}(100 \mu \mathrm{l})$ aliquots at $10-15$ minutes interval until all black carbon particles were digested. Samples were allowed to evaporate to dryness and cooled. A white ash was obtained from each sample and $1.8 \mathrm{ml}$ of deionised water and $0.2 \mathrm{ml}$ of $1 \%$ double-distilled nitric acid were added to each (presumably one could use $\mathrm{HCl}$ in situations where nitrate ion is undesirable). Samples were reheated at $90 \mathrm{oC}$ for 15 minutes to dissolve the residue (ash) and cooled. From this solution, $0.1 \mathrm{ml}$
$(100 \mu \mathrm{l})$ was taken in $10 \mathrm{ml}$ polypropylene tubes and made up to $5.0 \mathrm{ml}$ by adding the following:

- $0.01 \mathrm{ml}(10 \mu \mathrm{l})$ of 1:10 gallium, Ga, solution as internal standard;

- $4.89 \mathrm{ml}$ of $0.1 \%$ double-distilled nitric acid.

Each tube was shaken on a Vortex (Vortex Genie 2TM, Fisher Scientific Inc., Bohemia, NY, USA) and then, immediately used for the ICP-MS.

\section{Instrumentation procedure}

Selenium content was determined using the inductively coupled-mass spectrophotometry technique on a Perkin Elmer SCIEXTM ELAN® 9000 ICP-MS (Norwalk, CT, U.S.A.).

Internal standardisation with gallium in 2\% HNO3 (Perkin Elmer Life and Analytical Sciences, Shelton, CT, U.S.A.) was performed at $0.1 \mu \mathrm{g} / \mathrm{l}$ concentrations to all measuring solutions for the correction of matrix effects and quantification by external standardisation with standards prepared by serial dilution of $1 \mathrm{~g} / \mathrm{l}$ multi-element standard [(Perkin Elmer Life and Analytical Sciences, Shelton, CT, U.S.A.) Choi et, al [20]. Working standards for Se were freshly prepared by diluting $1000 \mathrm{ppm}$ pure Se stock solution (PerkinElmer) in a solution of $0.1 \% \mathrm{HNO}_{3}$. The ICP-MS was operated at $1,400 \mathrm{~W}$ forward power with a coolant flow rate of $13.5 \mathrm{l} / \mathrm{min}$, nebulizer gas flow rate of $1.15 \mathrm{l} / \mathrm{min}$ with concentric nebulizer. Spray chamber temperature was $4 \mathrm{oC}$ with cyclonic chamber. Sample delay and rinse times were $45 \mathrm{~s}$ with single reading. Sample uptake rate was $40 \mathrm{rpm}$.

\section{Statistical analysis}

Statistical analysis of data was performed using SPSS for Windows [(v17) SPSS Inc., Chicago]. The statistical programme was SPSS Statistics Data Editor. Data were presented as means and standard deviations. The student's t-test was used to determine the selenium content of grains and nuts in the region. Results are expressed as arithmetic means \pm standard deviationSD. A probability level of $\mathrm{P}<0.05$ was considered statistically significant.

\section{Results}

Most food samples were found to contain less than $7 \mu \mathrm{g} \mathrm{Se} /$ gramme as shown in Table 1.

Some of the samples contained considerably higher values ranging from $9.03 \pm 6.05 \mu \mathrm{g} / \mathrm{g}$ for Pennisetum glaucum (millet) to $14.19 \mu \mathrm{g} / \mathrm{g}$ for red Sorghum bicolor (sorghum). It is interesting that red sorghum had the highest selenium content of the food samples assayed despite not having the garlic-like smell reported for certain selenium compounds (Figure 1) [2].

As can be seen from Table 2, there is, for each crop, a wide variation in selenium content. Both in terms of lowest and highest selenium level detected and the mean values, red sorghum (Sorghum bicolor) has the highest followed by cowpea (Phaseolus vulgaris), and groundnut (Arachis hypogea), while white sorghum (Sorghum bicolor) has the lowest selenium content followed 
Table 1: Some Human selenoproteins*

\begin{tabular}{|c|c|c|}
\hline Selenoprotein & Function & Localization \\
\hline 15kDa Selenoprotein & $\begin{array}{l}\text { Gatekeepers for quality control by glucosylating misfolded } \\
\text { proteins, thereby preventing transport of improperly folded } \\
\text { glycoprotein's out of the ER. }\end{array}$ & $\begin{array}{l}\text { Localized in the ER; mainly } \\
\text { expressed in the prostatic gland, } \\
\text { testes, brain, kidney and liver, low } \\
\text { levels also Detected in skeletal } \\
\text { muscle, mammary gland and } \\
\text { trachea. }\end{array}$ \\
\hline Deiodinases (DIO) & $\begin{array}{l}\text { Cleave specific iodine carbon bonds in thyroid Hormones thereby } \\
\text { regulating their activity. }\end{array}$ & $\begin{array}{l}\text { Thyroid gland, anterior pituitary of } \\
\text { the brain. }\end{array}$ \\
\hline Deiodinase 1 DI01 & $\begin{array}{c}\text { Primarily deiodinates the } 5^{\prime} \text {-position of the phenolic Ring, but can } \\
\text { also deiodinate the 5-position. }\end{array}$ & $\begin{array}{l}\text { Homodimeric plasma membrane } \\
\text { protein. }\end{array}$ \\
\hline Deiodinase 2 DIO2 & Deiodinates the 5'-position with a preference for $\mathrm{T} 4$ over rT3. & $\begin{array}{l}\text { Central nervous system, pituitary } \\
\text { and thyroid glands, skeletal and } \\
\text { heart muscle, and in placental and } \\
\text { brown adipose tissue. }\end{array}$ \\
\hline \multirow{2}{*}{ Deiodinase 3 DIO3 } & Deiodinates the 5-position of the tyrosyl ring. & \multirow[b]{2}{*}{ Brain, placenta and pregnant uterus } \\
\hline & Inactivation of $\mathrm{T} 3$ and $\mathrm{T} 4$. & \\
\hline Glutathione Peroxidases & $\begin{array}{l}\text { Reduce and thereby detoxify peroxides to their respective alcohols } \\
\text { at the expense of (typically) glutathione. }\end{array}$ & $\begin{array}{l}\text { Ubiquitous homotetrameric } \\
\text { cytosolic enzymes. }\end{array}$ \\
\hline Glutathione peroxidase $1 \mathrm{GPx} 1$ & $\begin{array}{l}\text { Protect the cell from apoptosis, involved in the } \\
\text { regulation of virus production. }\end{array}$ & $\begin{array}{l}\text { Ubiquitous homotetrameric } \\
\text { cytosolic enzyme (often referred to } \\
\text { as cGPx). GPx1 is abundant in the } \\
\text { liver and erythrocytes. }\end{array}$ \\
\hline Glutathione peroxidase 2 GPx2 & $\begin{array}{l}\text { Accepts organic hydroperoxides (but not phosphatidyl choline } \\
\text { hydroperoxide) as substrates. GPx2 could be involved in apoptosis } \\
\text { and proliferation. }\end{array}$ & $\begin{array}{l}\text { Liver and within the gastrointestinal } \\
\text { system (but absent in heart and } \\
\text { kidney). GPx2 is oftenreferred to as } \\
\text { GI-GPx. }\end{array}$ \\
\hline Glutathione peroxidase 3 GPx3 & $\begin{array}{l}\text { Not convincingly resolved. So far, an efficient reductant. May have } \\
\text { regulatory functions. GPx3 is primarily expressed in the renal } \\
\text { proximal tubules and is used as a marker to monitor tubular } \\
\text { integrity }\end{array}$ & $\begin{array}{l}\text { Located extracellularly in the } \\
\text { plasma, hence the acronym } \\
\text { pGPx, and in the intestine. GPx3 } \\
\text { has the second highest plasma } \\
\text { concentration after selenoprotein P. }\end{array}$ \\
\hline \multirow[t]{2}{*}{ Glutathione peroxidase $4 \mathrm{GPx} 4$} & & \\
\hline & $\begin{array}{l}\text { Exhibits the broadest substrate specificity of all glutathione } \\
\text { peroxidases and can even reduce phospholipid hydroperoxides } \\
\text { (often referred to as ph-GPx), as a universal antioxidant in } \\
\text { the protection of biomembranes. GPx4 is also involved in } \\
\text { redox signaling and regulatory processes, such as inhibiting } \\
\text { lipoxygenases and apoptosis.Antioxidative function. }\end{array}$ & $\begin{array}{l}\text { Testes, where it accounts for almost } \\
\text { the total selenium content. }\end{array}$ \\
\hline Glutathione peroxidase $5 \mathrm{GPx} 5$ & Backup for the selenocysteine-containing isoforms in sperm. & \multirow{2}{*}{$\begin{array}{l}\text { Found exclusively in the epididymis } \\
\text { Only in olfactory epithelium and } \\
\text { embryonic tissues }\end{array}$} \\
\hline Glutathione peroxidase 6 GPx 6 & Suggests a function for GPx6 in olfaction. & \\
\hline Glutathione peroxidase 7 GPx7 & $\begin{array}{l}\text { Involved in breast cancer cell defense against oxidative stress } \\
\text { generated from polyunsaturated fatty acid metabolism. }\end{array}$ & Mammary gland. \\
\hline
\end{tabular}




\begin{tabular}{|c|c|c|}
\hline $\begin{array}{l}\text { Selenoproteins H, I, K, N, O, P, R, S, } \\
\text { T, V, W. }\end{array}$ & $\begin{array}{l}\text { Redox active proteins; heavy metals antidotes. Involved in the } \\
\text { retrotransport of misfolded luminal ER proteins to the cytosol for } \\
\text { proteosome degradation in a ubiquitin-dependent manner. }\end{array}$ & $\begin{array}{l}\text { Expressed in many tissues: liver, } \\
\text { transcripts are detected in skeletal } \\
\text { muscle, brain, lung and placenta. }\end{array}$ \\
\hline Selenophosphate & \multirow[b]{2}{*}{$\begin{array}{l}\text { Required for the formation of tRNA [Ser] Sec-bound } \\
\text { selenocysteine. }\end{array}$} & \multirow[b]{2}{*}{ All tissues. } \\
\hline Synthetase 2 & & \\
\hline $\begin{array}{c}\text { Thioredoxin Reductase } \\
\text { Family }\end{array}$ & Involved in a myriad of cellular and intercellular Processes. & \multirow[b]{2}{*}{ Is a testis-specific enzyme. } \\
\hline $\begin{array}{l}\text { Thioredoxin Glutathione } \\
\text { Reductase }\end{array}$ & $\begin{array}{l}\text { Specific function is currently unknown; it can reduce glutathione } \\
\text { disulfide. }\end{array}$ & \\
\hline
\end{tabular}

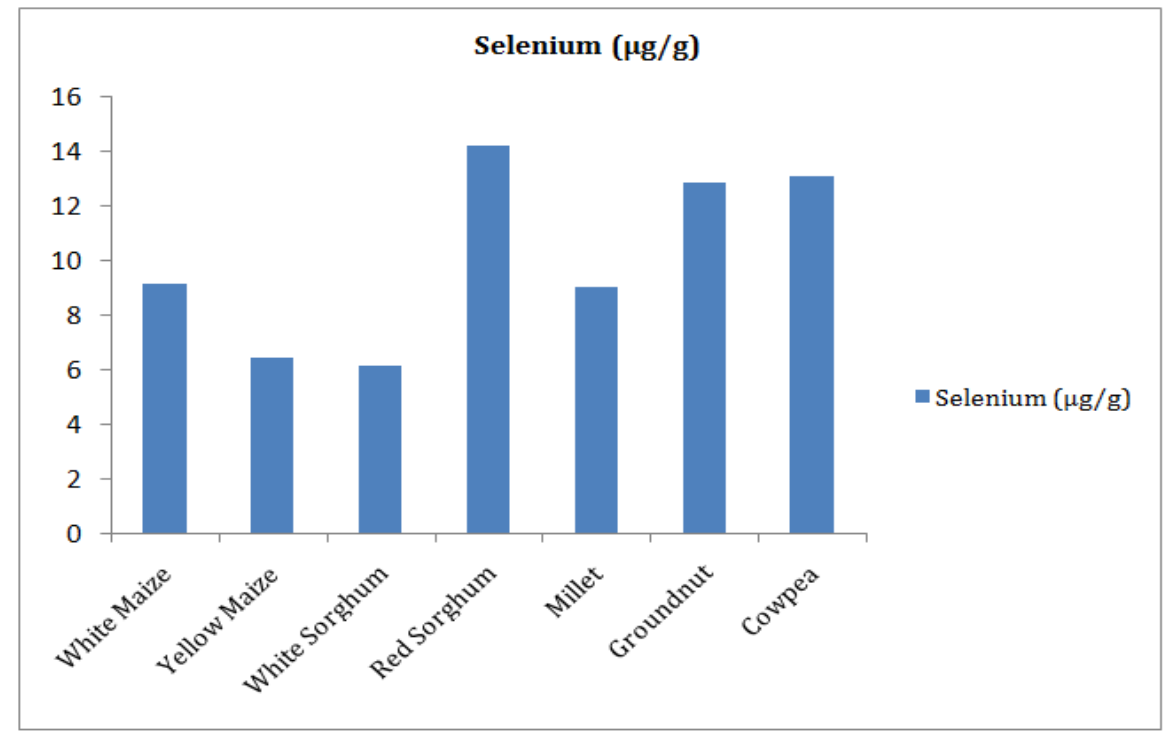

Figure 1: Graphical representation of selenium in the staple grains

Table $2 *$ : Selenium content ( $\mu \mathrm{g} / \mathrm{g}$ dry weight) of staple grains in various parts of the study area

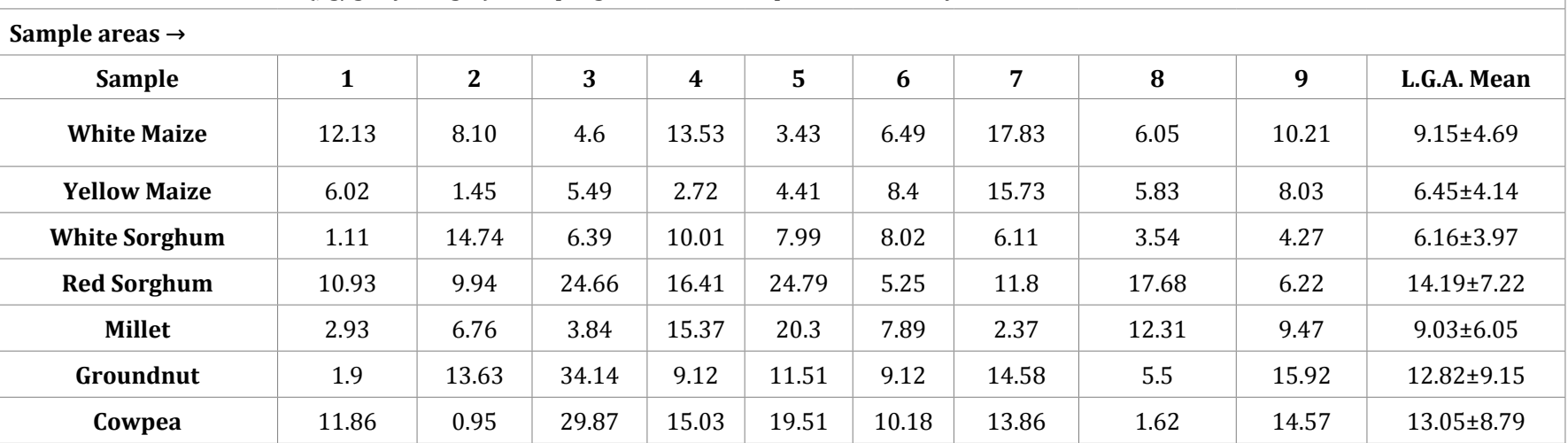

*Tabulated data are means \pm SD of 3 determinations for each sampling area 
Table 3* : Recommended Dietary Allowance (RDA) for Selenium

\begin{tabular}{|c|c|c|c|}
\hline Life Stage & Age & Males ( $\mu \mathrm{g} /$ day) & Females $(\mu \mathrm{g} /$ day $)$ \\
\hline Infants & $0-6$ months & $15(\mathrm{AI})$ & $15(\mathrm{AI})$ \\
\hline Infants & 7-12 months & $20(\mathrm{AI})$ & $20(\mathrm{AI})$ \\
\hline Children & 1-3 years & 20 & 20 \\
\hline Children & 4-8 years & 30 & 30 \\
\hline Children & 9-13 years & 40 & 40 \\
\hline Adolescents & $14-18$ years & 55 & 55 \\
\hline Adults & 19 years and older & 55 & 55 \\
\hline Pregnancy & all ages & - & 60 \\
\hline Breast-feeding & all ages & - & 70 \\
\hline
\end{tabular}

by yellow maize (Zea mays). In each case, the difference is statistically significant $(P<0.05)$. So, among the staple foodstuffs of the areas sampled, red sorghum and cowpea appear to be the richest source of dietary selenium followed by groundnut while white sorghum and yellow maize are the poorest, in that order.

Compared to the recommended dietary allowance of selenium, the samples analysed here have high quantities of selenium enough to meet the RDA Table 3 .

\section{Discussion}

The present paper reports values for selenium in a variety of common food items assayed using an inductively coupledplasma mass spectrophotometric technique. This technique allows the precise and accurate determination of selenium in the nanogramme range. The values found suggest that, with certain qualifications, there exists an adequate level of selenium in the human diet of north-central Nigeria. Selenium intake of humans ranges between very wide limits due to the consumption of foods with different selenium content. Combs showed in his study that in the different parts of the world there can be a difference of orders of magnitude in the selenium intake of people [22]. In China for example in the Keshan area the selenium intake varies between 7-11 $\mu \mathrm{g} /$ day, whereas in the Enshi county of central China it can reach several thousand $\mu$ g per day. In Europe selenium consumption of adults is around 30-100 $\mu$ g per day, in North America 60-220 $\mu \mathrm{g} /$ and in New Zealand's selenium deficient areas in some populations the daily selenium intake ranges between 19-80 $\mu \mathrm{g} /$ day. In some European countries selenium intake has decreased significantly in recent decades [23]. The main reason for this is the decreased import of bread making wheat from North America which contains generally much more selenium than the wheat grown in the UK [24].

The present results suggest that the levels of selenium in Nigerian staple foodstuffs (at least from the area studied) are sufficient for good nutrition. While this work was in progress, a review concerning selenium micronutrient appeared in Nigeria: the review reported results that generally agree with our data when expressed on an equivalent basis [25]. Thompson and Scott have shown earlier that 0.04 to $0.10 \mathrm{ppm}$ selenium are needed in the diet to prevent selenium deficiency in chickens depending on the vitamin E content of the diet [26]. Assuming a reasonable intake of animal protein and grain products, most Nigerians should receive at least these levels in their dietary. However, three important qualifications should be considered before it is flatly assumed that persons in Nigeria need not worry about their selenium intake. First of all, there may be certain local pockets of low selenium soil which could contribute to a possible deficiency just as there are known high selenium areas that are hazardous for agricultural purposes [27].

Secondly, little is known regarding the availability and biopotency of selenium as it occurs naturally in foods. There is a wide variation in the ability of various selenium compounds to prevent liver necrosis in rats [28]. Morris and Levander noted that most active forms of selenium (such as sodium selenite) are also the least stable chemically, whereas the relatively inert elemental selenium is essentially without value in alleviating selenium deficiency diseases [29]. Therefore, the total selenium content of foods may not be a valid indicator of their nutritional value. Finally, Morris and Levander also noted that it must be recognized that many selenium compounds are quite volatile and could thus be lost as a result of food cooking or processing [29]. This suggests that selenium losses as a result of cooking or processing could be a major factor in determining the selenium content of an individual's diet.

Insufficient selenium intake may negatively affect the activity of several selenium-responsive enzymes and proteins Table 1. Even when severe, isolated selenium deficiency does not usually result in obvious clinical illness [30]. Yet, compared to subjects with adequate selenium status, selenium-deficient individuals might be more susceptible to additional physiological stresses [30]. Prolonged selenium deficiency may likely contribute to Keshan and Kashin-Beck diseases [31]. 


\section{Conclusion}

The present results suggest that the levels of selenium in north-central Nigerian staple foodstuffs are sufficient for good nutrition. Assuming a reasonable intake of animal protein and grain products, most of the populations in the research area should receive at least these levels in their diet. There is an obvious need for more research concerning the chemical forms of selenium that occur in foods, the biological effectiveness of these various forms, and the possible effects of cooking and processing on these forms.

\section{Authors' contributions}

$\mathrm{KHJ}$ and ZSCO developed the study design; ZSCO supervised the field work; KHJ and BJS conducted the biochemical analysis; $\mathrm{KHJ}$ analyzed and interpreted the data. All authors contributed to manuscript preparation. All authors read and approved the final manuscript.

\section{Acknowledgment}

The authors gratefully acknowledge the excellent technical assistance of Mrs. Sandra Peterson. We thank Mr. Ewa Alugbo of the Academic Office of the University of Jos, Nigeria for helping in the analysis and interpretation of the data. The opinions expressed herein are those of the author(s) and do not necessarily reflect the views anybody or organization.

\section{References}

1. Oldfield JE. The two faces of selenium. The Journal of Nutrition.1987; 117: 2002-2008. doi.org/10.1093/jn/117.12.2002

2. Schwarz K, CM Foltz. Selenium as an integral part of Factor 3 against dietary necrotic liver degeneration. J. Amer. Chem. Soc. 1957; 79(12): 3292. doi: 10.1021/ja01569a087

3. Hartley WJ, AB Grant. A review of selenium-responsive diseases of animals inNew Zealand livestock. Federation Proc. 1961; 20:679.

4. Schubert JR, OH Muth, JE Oldfield, LF Remmert. Experimental results with selenium in white muscle disease of lambs and calves. Federation Proc. 1961;20:689-694.

5. Ross AC, Caballero B, Cousins RJ, Tucker KL, Ziegler TR. Modern Nutrition in Health and Disease. 11th ed. Baltimore: Lippincott Williams \& Wilkins;2014:265-276.

6. Odunukwe NN, Onwujekwe D, Ezechi O0, Ezobi P, Gbajabiamila T, Anyanwu R, et al. The role of selenium as adjunct to HAART among HIV-infected individuals who are advanced in their disease. In Sixteenth International AIDS Conference, Toronto, Canada 2006.

7. Anyabolu HC, Adejuyigbe EA, Adeodu 00. Serum micronutrient status of Haart-naive, HIV infected children in South Western Nigeria: A case controlled study. AIDS Research and Treatment; 2014. doi: $10.1155 / 2014 / 351043$

8. Kalio IS. Comparative study of selenium and zinc antioxidant in HIV sero positive individuals. IOSR Journal of Pharmacy and Biological Sciences (IOSRJPBS), 2014; 9(4): 47-50.

9. Akinloye O, Arowojolu AO, Shittu OB, Adejuwon CA, Osotimehin B. Selenium status of idiopathic infertile Nigerian males. Biological Trace Element Research. 2005; 104(1):9-18. doi:10.1385/BTER:104:1:009

10. Ahmed MK, Aliyu M, Yusuf T, Yusuf MK. Ameliorative effect of selenium yeast on blood glucose level in streptozotocin induced diabetes in wistar rats. Drugs. 1996; 80:23.

11. Rayman MP. Selenium and human health. Lancet. 2012; 379(9822):1256-1268. doi: 10.1016/S0140-6736(11)61452-9

12.Zhang X, Zarbl H. Chemopreventive doses of methylselenocysteine alter circadian rhythm in rat mammary tissue. Cancer Prevention Research. 2008; 1(2):119-127. doi: 10.1158/1940-6207.CAPR-080036

13. Yakubu DP, Dawet A, Olaleye NA. Effects of vitamin E and selenium on some blood parameter of Trypanosoma brucei brucei infected rats. British Journal of Applied Science \& Technology. 2014; 4(7):11001108.

14. Gromer S, Eubel JK, Lee BL, Jacob J. Human selenoproteins at a glance. Cell. Mol. Life Sci. 2005; 62(21). 2414-2437. doi: 10.1007/s00018005-5143-y

15. Chen J. An original discovery: selenium deficiency and Keshan disease (an endemic heart disease). Asia Pac J Clin Nutr. 2012; 21(3):320326.

16. Klein EA. 2004. Selenium: Epidemiology and Basic Science. J Urol. 2004;171(2 Pt 2):S50-S53. doi: 10.1097/01.ju.0000107837.66277.e9

17. Sunde RA, Bowman B, Russell R, eds. Selenium In: Present Knowledge in Nutrition. 9th ed. Washington, DC: International Life Sciences Institute; 2006:480-497.

18. Food and Agriculture Organization of the United Nations. West African Food Composition Table, Rome 2012, FAO, Viale delle Terme di Caracalla, 00153 Rome, Italy.

19. Hill AD, Patterson KY, Veillon C, Morris ER. Digestion of biological materials for mineral analysis using a combination of wet and dry ashing. Anal Chem. 1986;58(11):2340-2342.

20. Choi, M-K, Kang, M-H and Kim, M-H. The analysis of copper, selenium, and molybdenum contents in frequently consumed foods and an estimation of their daily intake in Korean adults. 2009; Biol Trace Elem Res. 2009;128(2):104-117. doi: 10.1007/s12011-008-8260-2

21. Food and Nutrition Board, Institute of Medicine. Selenium. Dietary reference intakes for vitamin $\mathrm{C}$, vitamin $\mathrm{E}$, selenium, and carotenoids. Washington, D.C.: National Academy Press; 2000:284-324. (National Academy Press)

22. Combs GF Jr. Selenium in global food systems. Br J Nutr. 2001; 85(5): 517-547.

23. Rayman MP. The argument for increasing selenium intake. Proc Nutr Soc. 2002; 61(2):203-215.

24. Tamas M, Mandoki Zs, Csapo J. The role of selenium content of wheat in the human nutrition. A literature review. Acta Univ. Sapientiae, Alimentaria. 2010;3:5- 34.

25. Adeniyi MJ, Agoreyo FO. Nigeria and the Selenium Micronutrient: A Review. Ann Med Health Sci Res. 2018;8:5-11

26. Thompson JN, ML Scott. Role of selenium in the nutrition of the chick. J Nutr. 1969;97(3): 335-342.

27. Rosenfeld I and 0 Beath. Selenium content of soils. Geobotany, Biochemistry, Toxicity and Nutrition. Academic Press, New York. 1964 ;41-51.

28.Schwarz K, A J Fredga. Biological potency of organic selenium compounds. J Biol Chem. 1969;244(8):2103-2110.

29. Morris VC, Levander O A. Selenium content of foods. J Nutrition. 1970;100:1383-1388.

30. Thomson CD. Assessment of requirements for selenium and adequacy of selenium status: a review. Eur J Clin Nutr. 2004;58(3):391-402.

31.Linus Pauling Institute. Selenium A publication of Linus Pauling Institute, Oregon State University, USA. 2015 